\title{
Olrog's Gull Larus atlanticus: specialist or generalist?
}

MARIANO M. MARTINEZ, ${ }^{*}$ JUAN P. ISACCH and MARTIN ROJAS

\section{Summary}

A study was made of the feeding behaviour of Olrog's gull Larus atlanticus in winter. Although feeding mainly on crabs they also, contrary to previous observations, made use of discarded offal, much as other species of gull. Such generalist feeding habits are likely to be beneficial to the conservation of the species.

\section{Introduction}

Olrog's Gull Larus atlanticus is considered to have a Vulnerable status (Collar et al. 1994). It is thought to be a specialized predator on crabs (Escalante 1966, 1984, Spivak and Senchez 1992, Yorio and Harris 1992, Burger and Gochfeld 1996) but occasionally also forages on discarded offal from fishing vessels (Jehl and Rumboll 1976), mussels Mytilus (Escalante 1966), fish (Olrog 1967) and insects (Spivak and Sánchez 1992).

During the austral spring Olrog's Gull breeds in small colonies in Bahía Blanca, Bahía San Blas and Bahía Bustamante (Argentina). Outside the breeding season its range extends from Puerto Deseado (Argentina) to Uruguay and southern Brazil (Olrog 1948, Escalante 1984, Yorio and Harris 1992, Collar et al. 1994).

Escalante (1966) suggested that the discontinuous distribution of Olrog's Gull was a consequence of its specialized foraging habits, being restricted to salt marshes and estuaries where the crabs Chasmagnatus granulatus and Cyrtograpsus angulata are abundant. An analysis of pellets from the Mar Chiquita Lagoon, Argentina, confirmed that crabs predominate in the diet of Olrog's Gull, thus restricting its distribution (Spivak and Sánchez 1992). However, observations we have made in Mar del Plata City, Argentina, suggest that Olrogis Gull may not be such a specialist.

The aim of this contribution is to describe the feeding habits of Olrog's Gull and address the question as to whether it is a generalist or specialist.

\section{Study area and methods}

Observations were made in Mar Chiquita Lagoon and Mar del Plata harbour, Buenos Aires, Argentina. The lagoon $\left(37^{\circ} 46^{\prime} \mathrm{S}, 57^{\circ} 27^{\prime} \mathrm{W}\right)$ has muddy and sandy beaches, Spartina salt marshes and many crabs (Olivier et al. 1972). Mar del Plata

\footnotetext{
* Deceased 12 March 1998.
} 
harbour $\left(38^{\circ} \mathrm{O}^{\prime} \mathrm{S}, 57^{\circ} 32^{\prime} \mathrm{W}\right)$ is the focal point of fishery activities in the region, providing supplementary food for many birds, mostly Kelp Gulls Larus dominicanus and Brown-hooded Gulls L. maculipennis, as well as pinnipeds.

Counts of gulls and observations of their activity were made during the winter months (April to November) in areas of similar size (30 ha). Studies were carried out in the harbour from 1989 to 1993 and in 1996, and at the lagoon from 1981 to 1984,1993 and in 1996.

\section{Results}

From May to September each year, adult, subadult and juvenile Olrog's Gulls were observed regularly in Mar del Plata and Mar Chiquita. Low numbers of juveniles remained throughout the year. The abundance was similar at both sites Mar Chiquita (mean 23.5 birds, range $3-58, n=22$ ), and in the harbour (mean 33.4 birds, range 5-76, $n=17$; Mann-Whitney $U: P=0.183$ ). The proportion of different ages was, in the harbour, $73 \%$ adults, $12 \%$ subadults and $15 \%$ juveniles, and in Mar Chiquita, 59\% adults, 30\% subadults and $11 \%$ juveniles.

In Mar Chiquita, both adults and juveniles fed predominantly on crabs Cyrtograpsus angulatus and Chasmagnathus granulata. Once they were seen to feed on snails Adelomedon sp. deposited on the shore by a storm, and once they were observed feeding on offal. In the harbour, individuals fed on waste discarded from boats around the unloading area. Also, groups of Olrog's Gulls, with Kelp Gulls, Brown-hooded Gulls and Trudeau's Terns Sterna trudeaui, were observed regularly feeding on discarded fish from nearby factories. Less often they fed on small mussels (Mytilidae) on the rocks. They were also observed feeding at the sewage outfall of Mar del Plata City.

In Mar Chiquita, they took crabs from the bottom while walking or swimming in shallow water. In deeper water they plunged into the water to catch crabs. Usually, the prey was carried to the shore and eaten completely. In a few cases gulls swallowed crabs immediately on capture. In September, gulls were seen to prey on the eggs of Cyrtograpsus angulatus, without killing the female. On one occasion, a juvenile fed on crabs killed and abandoned by an American Pied Oystercatcher Haematopus palliatus, which kills female crabs to eat their eggs.

In the harbour, foraging behaviour was linked to the activity of fishing boats and factories. When there was no boat activity Olrog's Gulls gathered in mixed flocks with Kelp Gulls on breakwaters, factory roofs, street lamps and on a beach near the harbour. When fishing boats began to arrive the gulls aggregated around them and fed by "dipping" (Harper et al. 1985) on offal thrown from the boats. Small pieces were swallowed in the air and larger pieces on the ground. Similar behaviour was observed at factories. In these feeding flocks we observed both intraspecific and interspecific kleptoparasitism, mainly by Kelp Gulls. Both species also flew along breakwaters looking for bait abandoned by sport fisherman.

\section{Discussion}

Based on our observations, Olrog's Gull, like most other gulls (Mudge and Ferns 1982, Burger and Gochfeld 1996) is a generalist forager during the non-breeding season in Buenos Aires Province. However, as previously observed (Escalante 
1966, Devillers 1977, Spivak and Sánchez 1992) in estuarine habitats it feeds primarily on crabs. This contrasts with Kelp Gull, which does not eat crabs in Mar Chiquita Lagoon, and Brown-hooded Gull, which has a catholic diet which includes crabs only occasionally.

Estuarine crabs are abundant in Argentina and Uruguay but few birds eat them (Spivak and Sánchez 1992). It is interesting to note that the Band-tailed Gull L. belcheri, considered conspecific with Olrog's Gull by some authors (Olrog 1958, Devillers 1977, Harrison 1985), has generalist habits along the Peruvian coast (Escalante 1966, Duffy 1980, J.P.I. pers. obs.).

In conclusion, Olrog's Gull is not restricted to estuarine habitats in winter, as suggested by Escalante (1984) and Spivak and Sánchez (1992). This more generalist feeding behaviour should improve the conservation prospects of the species.

\section{Acknowledgements}

We thank L. Ferrero and M. Zárate for their comments on this paper.

\section{References}

Burger, J. and Gochfield, M. (1996) Family Laridae. Pp. 572-623 in J. del Hoyo, A. Elliott and J. Sargatal, eds. Handbook of the birds of the World, 3. Barcelona: Lynx Edicions.

Collar, N. J., Crosby, M. J. and Stattersfield, A.J. (1994) Birds to watch 2. The world list of threatened birds. Cambridge, U.K.: BirdLife International (BirdLife Conserv. Series 4).

Devillers, P. (1977) Observations at a breeding colony of Larus (belcheri) atlanticus. Gerfaut 67: 22-43.

Duffy, D. C. (1980) Patterns of piracy by Peruvian seabirds: a depth hypothesis. Ibis 122: 521-525.

Escalante, R. (1966) Notes on the Uruguayan population of Larus belcheri. Condor 68: 507510.

Escalante, R. (1984) Problemas en la conservación de dos especies de Láridos sobre la costa atlántica de Sud América (Larus (belcheri) atlanticus y Sterna maxima). Rev. Mus. Arg. Ciencias Nat. "Bernardino Rivadavia". Zoología 13(1-60): 147-152.

Harper, P. C., Croxall, J. P. and Cooper, J. (1985) A guide to foraging methods used by marine birds in Antarctic and sub-Antarctic seas. Biomass Handbook 24: 1-22.

Harrison, P. (1985) Seabirds: an identification guide. Boston: Houghton Mifflin.

Jehl, J. R. and Rumboll, M. A. E. (1976) Notes on the avifauna of Isla Grande and Patagonia, Argentina. Trans. San Diego Soc. Nat. Hist. 18: 145-154.

Mudge, G. P. and Ferns, P. N. (1982) The feeding ecology of five species of gulls (Aves: Larini) in the inner Bristol Channel. J. Zool. Lond. 197: 497-510.

Olivier, S., Escofet, A. M., Penchaszadeh, P. and Orenzanz, J. M. (1972) Estudios ecológicos de la región estuarial de Mar Chiquita (Buenos Aires, Argentina) I: Las comunidades bentónicas. An. Soc. Cient. Arg. 193: 237-262.

Olrog, C. C. (1948) Observaciones sobre la avifauna de Tierra del Fuego y Chile. Acta Zool. Lilloana 5: 437-531.

Olrog, C. C. (1958) Notas ornitológicas sobre la colección del Instituto Miguel Lillo, Tucumán, Argentina. Acta Zool. Lilloana 5: 437-531.

Olrog, C. C. (1967) Breeding of the Band-tailed Gull (L. belcheri) on the Atlantic coast of Argentina. Condor 69: 42-48.

Spivak, E. D. and Sánchez, N. (1992) Prey selection of L. belcheri atlanticus in Mar Chiquita 
Lagoon, Bs.As. Argentina: a possible explanation for its discontinuous distribution. Rev. Chil. Hist. Nat. 65: 209-220.

Yorio, M. P. and Harris, G. (1992) Actualización de la distribución reproductiva, estado poblacional y de conservación de la Gaviota de Olrog (Larus atlanticus). Hornero 13: 200202.

MARIANO M. MARTINEZ, JUAN P. ISACCH ${ }^{1}$ and MARTIN ROJAS

Laboratorio de Vertebrados. Dpto. de Biología. Fac. de Cs. Exactas y Naturales.

Universidad Nacional de Mar del Plata. Funes 3250. (760o) Mar del Plata. Argentina.

${ }^{1}$ Comisión de Investigaciones Científicas de la Prov. de Buenos Aires.

\footnotetext{
${ }^{1}$ Author for correspondence; e-mail: jpisacch@mdp.edu.ar
} 